\title{
PROBLEMATIKA PEMBELAJARAN PENDIDIKAN AGAMA ISLAM DI SMP NEGERI 5 PADANGSIDIMPUAN
}

Oleh:

\section{Maulana Arafat Lubis ${ }^{1}$}

\begin{abstract}
Fokus Penelitian ini bagaimana Problematika Pembelajaran Pendidikan Agama Islam Di SMP Negeri 5 Padangsidimpuan. Secara umum penelitian dilakukan untuk mengetahui: 1. Bagaimana Problematika Pembelajaran Pendidikan Agama Islam tentang metode di SMP Negeri 5 Padangsidimpuan, 2. Bagaimana problematika Pembelajaran Pendidikan Agama Islam tentang media di SMP Negeri 5 Padangsidimpuan?

Penelitian ini menggunakan pendekatan kualitatif deskriptif. Instrument pengumpulan data yang digunakan adalah observasi, wawancara dengan sumber datanya adalah guru Pendidikan Agama Islam, dan siswa/siswi. Analisis dilakukan dengan menggunakan metode komparasi konstan. Metode Penelitian yang dilakukan dalam penulisan ini adalah metode deskriftif kualitatif, teknik pengumpulan data kelapangan melalui observasi, dan wawancara. Teknik pengelolaan dan analisis data, reduksi data, penyajian data, kesimpulan dan verifikasi data. Teknik menjamin keabsahan data, ketekunan pengamatan, triangulasi, pengecekan anggota.

Tujuan penelitian ini adalah untuk mengetahui bagaimana problematika dalam proses pembelajaran pendidikan agama Islam di SMP Negeri 5 Padang Sidimpuan, Untuk menemukan problematika pembelajaran pendidikan agama Islam di SMP Negeri 5 Padansidimpuan.

Hasil penelitian ini menunjukkan bahwa problematika pembelajaran Pendidikan Agama Islam di SMP Negeri 5 Padangsidimpuan, mengenai problematika pembelajaran Pendidikan Agama Islam problematika metode pembelajaran Pendidikan Agama Islam (PAI) di SMP Negeri 5 Padangsidimpuan sangat dipetakakan kepada tiga masalah problematika, yaitu: problematika pengetahuan, kognitif guru, kompotensi teknik guru dan kompetensi strategis guru dalam menerapkan metode pembelajaran. Bahwa metode, dan media, kurang sesuai dalam penetapan proses pembelajaran
\end{abstract}

${ }^{1}$ Penulis adalah Dosen Prodi Pendidikan Guru Madrasah Ibtidaiyah IAIN Padangsidimpuan 
tidak sesuai dengan RPP. Berdasarkan yang penulis lakukan bahwa masalah metode yang penulis temukan bermasalah, begitu juga dengan media bahwa problematika media pembelajaran Pendidikan Agama Islam (PAI) di SMP Negeri 5 Padangsidimpuan sangat diklasipikasi kepada dua hal problematik, yaitu: problem ketersediaan media dan problem pemanfaatan media pembelajaran.

Keywords: Problematika pembelajaran, Pendidikan Agama Islam

\section{Latar Belakang}

Kegiatan pembelajaran memiliki kedudukan dan posisi bagi pendidikan, kegiatan pembelajaran yang dirancang sesuai dengan sasaran/target pembelajaran dapat membantu para guru dalam melaksanakan pembelajaran untuk mengantarkan murid kepada tujuan dan mengatasi masalah yang mungkin timbul dalam pembelajaran secara holistik. Proses pembelajaran yang dilakukan, baik di lembaga formal maupun lembaga non formal merupakan inti dari kegiatan sekolah/madrasah. Seorang tenaga pengajar berkewajiban untuk menciptakan situasi belajar yang efektif dan kondusif agar murid dapat dan menguasai materi secara baik.

Pembelajaran Pendidikan Agama Islam adalah kegiatan yang dilakukan oleh seorang guru untuk mencapai keberhasilan dalam memperkuat iman dan ketakwaan siswa terhadap Tuhan Yang Maha Esa.Pembelajaran Pendidikan Agama Islam merupakan mata rantai alur kehidupan muslim yang diaplikasikan dalam aktivitas sehari-hari. Pembelajaran Pendidikan Agama Islam sebagai suatu harta ilmuan diberikan kepada peserta didik yang membutuhkan dan dijadikan pula aset meraih kehidupan yang terorganisir dan terarah demi kepentingan kebahagiaan di dunia dan akhirat. $^{2}$

Pendidikan Agama Islam adalah merupakan mata pelajaran yang dikembangkan dari ajaran-ajaran dasar yang terdapat dalam Agama Islam. Ajaranajaran dasar tersebut terdapat dalam Alquran dan Hadis. Pendidikan Agama Islam bertujuan meningkatkan keimanan, pemahaman, penghayatan dan pengalaman peserta didik tentang Agama Islam sehingga menjadi manusia dan bertakwa kepada Allah SWT. Serta berakhlak mulia dalam kehidupan pribadi, bermasyarakat, berbangsa dan bernegara.Pendidikan Agama Islam diajarkan pada lembaga pendidikan formal menanamkan, membimbing setiap orang atau anak

${ }^{2}$ Asfiati, Manajemen Pembelajaran Pendidikan Agama Islam (Bandung: Citapustaka Media, 2013), hlm. 43-44. 
didik beriman, saleh, taat terhadap perintah Allah, berakhlak mulia dan berpengetahuan dalam menjalani kehidupan berbangsa dan bernegara.

Pendidikan Agama Islam adalah pendidikan dengan melalui ajaran-ajaran agama Islam, yaitu berupa bimbingan dan asuhan terhadap anak didik agar nantinya setelah selesai dari pendidikan ia dapat memahami, menghayati dan mengamalkan ajaran-ajaran agama Islam itu sebagai suatu pandangan hidupnya demi keselamatan dan kesejahteraan hidup di dunia maupun hidup di akhirat kelak. ${ }^{3}$ Di dalam Garis-garis Besar Program Pembelajaran Pendidikan Agama Islam (GBHN PAI) di sekolah umum dalam Muhaimin, dijelaskan bahwa:

"Pendidikan agama Islam adalah usaha sadar untuk menyiapkan siswa dalam menyakini, memahami, menghayati dan mengamalkan agama Islam melalui kegiatan bimbingan, pengajaran, dan latihan dengan memperhatikan tuntunan untuk menghormati agama lain dalam hubungan kerukunan antar umat beragama dalam masyarakat untuk mewujudkan persatuan nasional."4

Dari pengertian tersebut dapat ditemukan beberapa hal yang perlu diperhatikan dalam pembelajaran Pendidikan Agama Islam,yaitu:

1. Pendidikan Agama Islam sebagai sebagai usaha sadar, yakni suatu kegiatan bimbingan, pengajaran dan latihan yang dilakukan secara berencana dan sadar atas tujuan yang hendak dicapai.

2. Perserta didik yang hendak disipkan untuk mencapai tujuan, peningkatan keyakinan, pemahaman, penghayatan, dan pengalaman terhadap ajaran agama Islam.

3. Pendidik atau guru Pendidikan Agama Islam (GPAI) yang melakukan kegiatan bimbingan, pengajaran dan latihan secara sadar terhadap peserta didiknya untuk mencapai tujuan Pendidikan Agama Islam.

4. Kegiatan (pembelajaran) Pendidikan Agama Islam diarahkan untuk meningkatkan keyakinan, pemahaman, penghayatan dan pengalaman ajaran Agama Islam Perserta didik untuk membentuk kesalehan atas kualitas pribadi dan sekaligus untuk membentuk kesalehan sosial. Dalam arti, kualitas pribadi itu diharapkan dapat memancar dari luar dalam hubungan keseharian dengan manusia lainnya (bermasyarakat), baik yang seagama maupun yang tidak seagama, serta dalam berbangsa dan bernegara sehingga dapat terwujud

${ }^{3}$ Muhaimin, Paradigma Pendidikan Islam (Bandung: PT. Remaja Rosdakarya, 2002), hlm. 73.

${ }^{4}$ Ibid., hlm. 77. 
persatuan dan kesatuan nasional dan bahkan persatuan dan kesatuan antar sesama manusia.

Pendidikan Agama Islam bertujuan meningkatkan keimanan, pemahaman, penghayatan dan pengalaman peserta didik tentang agama Islam sehingga menjadi beriman dan bertakwa kepada Allah SWT serta berakhlak mulia dalam kehidupan pribadi, bermasyarakat, berbangsa dan bernegara (GBPP PAI, 1994). ${ }^{5}$ Dari tujuan tersebut dapat ditarik beberapa dimensi ruang lingkup keimanan yang hendak dicapai dan dituju oleh kegiatan pembelajaran pendidikan agama Islam, yaitu:

1. Dimensi keimanan peserta didik terhadap ajaran Agama Islam.

2. Dimensi pemahaman dan penalaran (intelektual) atau keilmuan peserta.

3. Dimensi penghayatan dan pengalaman batin yang dirasakan keimanan peserta didik dalam menjalankan agama Islam.

4. Dimensi pengalamannya, dalam arti bagaimana ajaran Islam yang diimani, dipahami dan dihayati atau diinternalisasi peserta didik itu agar mampu menumbuhkan motivasi dalam dirinya untuk mengarakkan, mengamalkan dan menaati ajaran agama dan nilai-nilainya dalam kehidupan pribadi sebagai manusia yang beriman dan bertakwa kepada Allah SWT serta mengaktualisasikan dalam kehidupan bermasyarakat, berbangsa dan bernegara.

Dalam kegiatan belajar mengajar selalu melibatkan dua pelaku aktif, yaitu guru dan siswa. Guru sebagai pengajar merupakan pencipta kondisi belajar siswa yang didesain secara sengaja, sistemais, dan berkesinambungan. Sedangkan sebagai subyek pembelajaran merupakan pihak yang menikmati kondisi belajar yang diciptakan guru.Undang-Undang RI No. 20 Tahun 2003 tentang Sistem Pendidikan Nasional (SIKDISNAS).Di dalam UU No. 20 Tahun 2003, menetapkan bahwa Kurikulum Pendidikan Dasar dan Menengah di Indonesia harus memuat Pendidikan Agama. ${ }^{6}$ Dalam Undang-Undang RI No. 20 Tahun 2003 tentang Sistem Pendidikan Nasional (SIKDISNAS). Di sebutkan bahwa:

"Pendidikan Nasional berfungsi mengembangkan kemampuan dan membentuk watak serta peradaban bangsa yang bermartabata dalam rangka mencerdaskan kehidupan bangsa, bertujuan untuk mengembangkan potensi peserta didik agar menjadi manusia yang beriman dan bertakwa kepada Tuhan yang Maha Esa, berakhlak mulia, sehat, berilmu, cakap,

\footnotetext{
${ }^{5}$ Ibid., hlm. 78.

${ }^{6}$ Undang-undang Sistem Pendidikan Nasional, Media Wacana Press (Jogjakarta: Cet. I, 2003), hlm. 27.
} 
kreatif, mandiri, dan menjadi warga Negara yang demokratis serta bertanggung jawab". ${ }^{7}$

Dalam penjelasan Undang-Undang tersebut dinyatakan bahwa Pendidikan Agama dimaksudkan untuk membentuk peserta didik menjadi manusia yang beriman dan bertakwa kepada Tuhan Yang Maha Esa serta berakhlak mulia. ${ }^{8}$ Pendidikan Islam secara sederhana diartikan sebagai pendidikan berdasarkan ajaran Islam, memiliki ajaran yang kompreheshif (bertujuan dunia dan akhirat). ${ }^{9}$ Dalam Pendidikan Nasional di Indonesia menjadikan mata pelajaran agama sebagai mata pelajaran pokok.Maksudnya bahwa mata pelajaran tersebut sangat menentukan dalam memberi penilaian terhadap status seorang siswa baik pada penentuan naik kelas atau ketentuan ujian akhir. ${ }^{10}$

Berdasarkan studi pendahuluan yang penulis laksanakan dilapangan di sekolah SMP Negeri 5 Padangsidimpuan bahwa pelaksanaan pembelajaran Pendidikan Agama Islam kalau dilakukan maksimalakan kecilsudah dilakukan semaksimal mungkin yakni dengan melaksanakan antara lain: metode dan media, penyediaan sarana dan prasarana yang mendukung pembelajaran Pendidikan Agama Islam, tetapi kenyataannya masih ada di antara guru agama yang tidak menggunakan media pembelajaran secara teratur, dan metode pembelajarannya itu-itu saja tidak diganti-ganti, dan media tidak digunakan. Hal ini termasuk problematika pembelajaran Pendidikan Agama Islam.

Kenyataannya tersebut menunjukkan bahwa yang diharapkan pembelajaran tujuan Pendidikan Agama Islam di SMP Negeri 5 Padangsidimpuan belum tercapai,dan masih ada problematika yang muncul guru tidak menguasai metode dan media pembelajaran.Hal ini terjadi disebabkan antara lain cara/metode yang kurang tepat atau mungkin dipengaruhi oleh fasilitas yang terbatas, guru yang kurang professional, lingkungan yang tidak mendukung, materi yang kurang tepat dan lain-lain.

Berdasarkan fenomena di atas, maka penulis sangat tertarik untuk melakukan penelitian dan mengangkat permasalahan ini untuk dijadikanjudul skripsi yaitu:"Problematika Pembelajaran Pendidikan Agama Islam di SMP Negeri 5 Padangsidimpuan".

${ }^{7}$ Abd Azis Albone, Pendidikan Agama Islam dalam Persfektif Multikulturalisme (Jakarta: Cipta Mandiri, 2006), hlm. 5.

${ }^{8}$ Ibid., hlm. 62.

${ }^{9}$ Abuddin Nata, Filsafat Pendidikan Islam (Jakarta: Logos Wacana Ilmu, 1997), hlm. 166.

${ }^{10}$ Haidar Putra, Pendidikan Islam di Indonesia (Jakarta: Cita Pustaka Media, 2001), hlm. 116. 


\section{Fokus Penelitian}

Kegiatan tentang problematika Pembelajaran Pendidikan Agama Islam menyangkut banyak aspek, yaitu aspek tujuan, materi, media, metode atau strategi, subjek dan objek serta evaluasi pembelajaran. Agar penelitian ini lebih fokus, maka peneliti hanya akan melakukan riset pada dua aspek, yaitu aspek metode/strategi dan media pembelajaran.

\section{Rumusan Masalah}

Berdasarkan fokus di atas maka yang menjadi rumusan masalah dalam penelitsian ini adalah:

1. Bagaimana problematika pembelajaran Pendidikan Agama Islam tentang metode dan media di SMP Negeri 5 Padangsidimpuan?

2. Mengapa problematikapembelajaran Pendidikan Agama Islamdi SMP Negeri 5 Padangsidimpuan?

\section{Pembelajaran}

\section{Kajian Teori}

Secara etimologi Pembelajaran sering didentikkan dengan kata mengajar berasal dari kata dasar "ajar" yang berarti petunjuk yang diberikan kepada orang supaya diketahui (diturut) ditambah dengan awalan "pe" dan akhiran "an" menjadi "pembelajaran"yang berarti proses, perbuatan atau mengajarkan sehingga anak didik mau belajar. ${ }^{11}$ Dalam buku yang berjudul "Introduction to Psychology", Margon menyebutkan bahwa belajar adalah setiap perubahan yang relatif menetap dalam tingkah laku yang terjadi sebagai suatu latihan atau pengalaman. ${ }^{12}$

Pembelajaran secara terminologi yaitu mempunyai pengertian yang mirip dengan pengajaran, walaupun mempunyai konotasi yang berbeda.dalam konteks pendidikan, guru mengajar supaya peserta didik dapat belajar dan menguasai isi pelajaran hingga menjadi suatu objektif yang ditentukan (aspek kognitif), serta keterampilan (aspek psikomotorik) seorang peserta didik. Pembelajaran adalah proses belajar mengajar atau terlaksananya hubungan timbal balik antar guru dengan siswa tidak biasa belajar tanpa bimbingan guru dan sebaliknya pula guru tidak bisa mengajar tanpa adanya siswa yang akan diajar. ${ }^{13}$ Jadi pembelajaran ialah membelajarkan siswa menggunakan asas

${ }^{11}$ Tim Penyusun Departemen Pendidikan dan Kebudayaan, Kamus Besar Bahasa Indonesia, (Jakarta: Balai Pustaka, 1991), hlm. 200.

${ }^{12}$ Ngalim Purwanto, Psikologi Pendidikan, (Bandung Remaja Rosdakarya, 1990), hlm. 84.

${ }^{13}$ Dimyati, Belajar dan Pembelajaran, (Jakarta: Rineka Cipta, 2006), hlm. 7. 
pendidikan maupun teori belajar merupakan penentu utama keberhasilan pendidikan.Pembelajaran merupakan proses komunikasi dua arah, mengajar dilakukan oleh pihak guru sebagai pendidik, sedangkan belajar dilakukan oleh peserta didik atau murid. ${ }^{14}$

Pembelajaran adalah suatu kombinasi yang tersusun meliputi unsurunsur manusiawi, material, fasilitas, perlengkapan, dan prosedur yang saling mempengaruhi mencapai tujuan pembelajaran. ${ }^{15}$ Sedangkan dalam UndangUndang Sistem Pendidikan Nasional Bab I Pasal I No. 20 Tahun 2003 menyatakan bahwa: "Pembelajaran adalah proses interaksi peserta didik dengan pendidik dan sumber belajar pada suatu lingkungan belajar". ${ }^{16}$ Pembelajaran atau pengajaran menurut Degeng yang dikutip dalam buku Hamzah B.Uno: Perencanaan pembelajaran, adalah upaya untuk membelajarkan siswa. Dalam pengertian ini secara implisit dalam pengajaran terdapat kegiatan memilih, menetapkan, mengembangkan metode untukmencapai hasil pengajaran yang diinginkan. ${ }^{17}$

Dari pengertian tersebut dapat disimpulkan bahwa pembelajaran itu adalah proses belajar mengajar Pendidikan Agama Islam yang dilakukan guru dan siswa dengan berbagai cara sehingga terjadi hubungan timbal balik dalam pelaksanaan belajar mengajar karena di sini ada dua orang penentu dalam proses belajar mengajar guru sebagai pendidik sedangkan belajar dilakukan oleh peserta didik atau murid yang tersebut.

\section{Komponen-Komponen Pembelajaran}

Komponen adalah bagian dari tubuh dalam strategi pembelajaran. Proses belajar mengajar di sekolah merupakan suatu sistem interaksi, artinya suatu keseluruhan yang terdiri dari komponen yang berinteraksi antara satu sama lain. Adapun komponen-komponen tersebut adalah:

a. Komponen Tujuan pembelajaran

Tujuan pembelajaran memiliki ciri penting dalam kegiatan belajar mengajar dengan tujuan memberikan arah yang jelas dan dapat diartikan sebagai suatu cita-cita yang ingin dicapai pelaksana suatu kegiatan.Dengan membentuk anak didik dalam perkembangan tertentu.Inilahyang dimaksud

${ }^{14}$ Syaiful Sagala, Konsep dan Makna Pembelajaran (Bandung: Alfabeta 2013), hlm. 61.

${ }^{15}$ Oemar Hamalik, Kurikulum dan Pembelajaran (Jakarta: Bumi Aksara, 2008), hlm. 57.

${ }^{16}$ Depag, Undang-undang dan Pemerintahan RI tentang Pendidikan (Jakarta: Dirjen Pendidikan Islam Departemen Agama RI, 2006), hlm. 5.

${ }^{17}$ Muhaimin, Pradigma Pendidikan Islam (Bandung: PT. Remaja Rosdakarya, 2002), hlm. 56. 
dengan kegiatan pembelajaran "sadar tujuan.Jadi tujuan adalah suatu cita-cita yang ingin dicapai dari pelaksanaan suatu kegiatan pembelajaran.Tidak ada suatu kegiatan yang diprogramkan tanpa tujuan.Sebagai unsur penting untuk suatu kegiatan, maka dalam kegiatan apapun tujuan tidak biasa diabaikan. ${ }^{18}$

Dikatakan bahwa tujuan pendidikan nasional untuk mencerdaskan bangsa dan mengembangkan manusia Indonesia seutuhnya, dapat di jelaskan dengan ciri-ciri sebagai berikut:

1) Beriman dan bertakwa kepadaTuhan Yang Maha Esa

2) Berbudi pekerti luhur

3) Memiliki pengetahuan dan keterampilan

4) Sehat jasmani dan rohani

5) Kepribadian yang mantap dan mandiri

6) Bertanggung jawab terhadap masyarakat dan bangsa. ${ }^{19}$

Agar tujuan Pendidikan Nasional tersebut tercapai, maka dari itu, tujuan harus dirumuskan secara baik dan matang agar tercapai murid/santri yang memiliki akhlak yang mulia.

b. Komponen Bahan pelajaran

Bahan pelajaran adalah substansi yang akan disampaikan dalam proses belajar mengajar. Sedangkan Sudirman NK mengatakan bahwa bahan pelajaran adalah sesuatu yang membawa pesan intuk tujuan pengajaran. Tanpa bahan pelajaran proses belajar mengajar tidak akan berjalan dengan lancar dan mempelajari bahan pelajaran yang akan disampaikan kepada anak didik dengan baik. $^{20}$ OLeh karena itu, materi pembelajaran harus dipersiapkan dengan baik agar pelaksanaan pembelajaran dapat mencapai sasaran.Sasaran tersebut harus sesuai dengan standar kompetensi dan kompetensi dasar yang harus dicapai oleh siswa. Artinya, materi yang ditentukan untuk kegiatan pembelajaran hendaknya materi yang benar-benar menunjang tercapainya standar kompetensi dan kompetensi dasar serta tercapainya indikator.

c. Komponen Metode/Strategi

Strategi dan metode merupakan komponen ketiga dalam pengembangan kurikulum. Komponen ini merupakan komponen yang memiliki peran yang sangat penting, sebab berhubungan dengan implementasi kurikulum.

${ }^{18}$ Syaiful Bahri Djamarah dan Aswan Zain, Strategi Belajar Mengajar (Jakarta: Rineka Cipta, 2006), hlm. 42.

${ }^{19}$ Hasbullah, Dasar-dasar Ilmu Pendidikan, (Bandung: Wacana Prima, 2007), hlm.11.

${ }^{20}$ Mardianto, Media Pembelajaran Pendidikan Agama Islam (Medan: Fakultas Tarbiyah Istitut Agama Islam Negeri Sumatera Utara, 2010), hlm, 17-18. 
Bagaimanapun bagus dan idealnya tujuan yang harus dicapai tanpa strategi yang tepat untuk mencapainya,maka tujuanitu tidak dapat dicapai. Strategi meliputi rencana, metode dan perangkat kegiatan yang direncanakan untuk mencapai tujuan tertentu. Sejalan dengan pendapat di atas, Rakajoni mengartikan strategi pembelajaran sebagai poladan urutanumum perbuatan guru-siswa dalam mewujudkan kegiatan belajar mengajar untuk mencapai tujuan yang telah ditentukan.

Dari kedua pengertian diatas, ada dua hal yang patut kita cermati. Pertama, strategi pembelajaran merupakan rencana tindakan (rangkaian kegiatan) termasukpenggunaan metode dan pemanfaatan berbagai sumber daya/kekuatan dalam pembelajaran. Ini berarti penyusunan suatu strategi baru sampai pada proses penyusunan rencana kerja belum sampai pada proses penyusunan kerja belum sampai pada tindakan. Kedua, Strategi disusun untuk mencapai tujuan tertentu. Artinya, arah dari semua keputusan penyusunan strategi adalah pencapaian tujuan.Dengan demikian penyusunan langkahlangkah pembelajaran, pemanfaatan berbagai fasilitas dan sumber belajar semuanya diarahkan dalam upaya pencapaiaan tujuan. ${ }^{21}$

\section{d. Komponen Media Mengajar}

Media Mengajar merupakan segala macam bentuk perangsang dan alat yang disediakan guru untuk mendorong siswa belajar. Perumusan di atas menggambarkan pengertian media yang sering disebut sebagai audio Visual aid, serta berbagai bentuk alat penyaji perangsang belajar, berupa alat-alat elektronika seperti mesin pengajaran, film, audio cassette, video cassette, televisi, dan computer.

Dengan demikian, dari penjelasan di atas dapa disimpulkan bahwa media memiliki posisi yang sangat penting, karena dapat membantu untuk memudahkan para siswa dalam proses pembelajaran berlangsung. Dengan demikian, adanya media sangat berguna dalam proses pembelajaran.

e. Komponen Evaluasi Pengajaran

Komponen utama selanjutnya setelah rumusan tujuan, bahan ajar, strategi mengajar,dan media mengajar adalah evaluasi dan penyempurnaan. Evaluasi ditujukanuntuk menilai pencapaiaan tujuan-tujuan yang telah ditentukan serta menilai proses pelaksanaan mengajar, penentuan sekuens

${ }^{21}$ Toto Ruhimat, Kurikulum\& Pembelajaran (Jakarta: PT. Raja Grafindo Persada, 2011), hlm. 53-54. 
bahan ajar,strategi, dan media mengajar. ${ }^{22}$ Evaluasi merupakan komponen terakhir dalam system proses pembelajaran. Evaluasi bukan saja berfungsi untuk melihat keberhasilan siswa dalam proses pembelajaran, tetapi juga berfungsi sebagai umpan balik bagi guru atas kinerjanya dalam pengelolaan pembelajaran. Melalui evaluasi kita dapat melihat kekurangan dalam pemanfaatan berbagai komponen system pembelajaran. ${ }^{23}$

Jadi dapat diketahui bahwa komponen pembelajaran dalam proses belajar mengajar sangat di perlukan di antara lima komponen karena kelima komponen menentukan dan menganalisis kelima komponen pokok dalam proses pembelajaran di atas, akan dapat membantu kita dalam memprediksi keberhasilan proses pembelajaran.

\section{Faktor-faktor yang Berpengaruh Terhadap Sistem Pembelajaran}

Terdapat beberapa faktor yang dapat mempengaruhi kegiatan proses sistem penbelajaran, di antaranya faktor guru, faktor siswa, faktor sarana, faktor alat, faktor media dan faktor lingkungan. Faktor-faktor tersebut dapat dijelaskan sebagai berikut:

a. Faktor Guru

Guru adalah sebagai komponen yang sangat menentukan dalam implementasi suatu starategi pembelajaran. Tanpa guru, bagaimana pun bagus dan idealnya suatu starategi, maka starategi itu tidak dapat diaplikasikan dengan baik. $^{24}$

\section{b. Faktor Siswa}

Siswa adalah organisme yang unik dan berkembang sesuai dengan tahap perkembangannya masing-masing. Dapat juga dikatakan bahwa siswa orang yang memerlukan bantuan dari orang dewasa dalam mengembangkan dirinya. ${ }^{25}$ Dimana siswa memiliki perbedaan antara satu siswa dengan siswa yang lainnya. Perbedaan tersebut yang harus diperhatikan dan dipahami oleh setiap guru sehingga proses pembelajaran dapat berjalan dengan lancar.

Faktor yang data mempegaruhi siswa dalam proses pembelajaran meliputi latar belakang siswa yaitu jenis kelamin, tempat tinggal siswa, tingkat

\footnotetext{
${ }^{22}$ Sukanto, Pengembangan Kurikulum (Medan: Fakultas Tarbiyah Istitut Agama Islam Negeri Sumatera Utara, 2010), hlm, 55.

${ }^{23}$ Wina Sanjaya, Strategi Pembelajaran Berorientasi Standar Proses Pendidikan (Jakarta: Kencana, 2008), hlm. 52.

${ }^{24} \mathrm{Ibid}$., hlm. 60.

${ }^{25}$ Syafaruddin, Ilmu Pendidikan Perspektif Islam (Bandung: Citapustaka Media, 2005), hlm. 131.
} 
ekonomi siswa dan lain sebagainya. Dari sudut pribadinya yang meliputi kemampuan dasar, pengetahuan dan sikap.Tidak dapat disangkal bahwa setiap siswa memiliki kemampuan yang berbeda yang dapat dikategorikan dalam tingkat tinggi, sedang, dan rendah. Perbedaan tersebut menuntut perlakuan yang berbeda pula baik dalam penempatan maupun dalam pengelompokan siswa.

\section{c. Faktor Sarana dan Prasarana}

Sarana adalah segala sesuatu yang mendukung secara langsung terhadap kelancaran proses pembelajaran. Misalnya media pembelajaran, alat-alat pelajaran, perlengkapan sekolah, kamar kecil dan sebagainya. Dengan demikian sarana dan prasarana merupakan komponen penting yang dapat mempengaruhi proses pembelajaran. ${ }^{26}$ Dengan kata lain, sarana dan prasarana yang lengkap dalam proses pembelajaran dapat mempengaruhi keberhasilan. Sesuai dengan prinsip di atas bahwa sarana adalah salah satu hal yang penting bagi tercapainya tujuan pembelajaran.

d. Faktor Lingkungan

Secara umum lingkungan adalah segala sesuatu yang ada di sekitar siswa baik benda-benda maupun peristiwa-peristiwa yang terjadi. ${ }^{27}$ Dilihat dari dimensi lingkungan ada dua faktor yang dapat mempengaruhi proses pembelajaran, yaitu faktor organisasi kelas dan faktor iklim atau kondisi kelas.

\section{Problematika Pembelajaran Pendidikan Agama Islam}

Di dalam pembelajaran Pendidikan Agama Islam telah lumrah dikatakan ada suatu problem atau masalah. Namun sebelum terlihat problematika yang dimaksud di dalam Pendidikan Agama Islam maka lebih dahulu diuraikan apa yang dimaksud dengan problematika. Menurut Tim Penyusun Kamus Pusat Pembinaan dan Pembangunan Bahasa mengartikan "Problematika adalah berasal dari kata problem yang artinya masalah atau persoalan". ${ }^{28}$ Sedangkan menurut Puis, problematika adalah: "Sesuatu masih menimbulkan masalah, masih belum dapat dipecahkan atau permasalahan". ${ }^{29}$

Problematika adalah sesuatu yang masih menimbulkan masalah, masih belum dapat dipecahkan atau permasalahan. Jadi, problematika adalah sesuatu yang menimbulkan masalah bagi seseorang dalam memberikan dan

\footnotetext{
${ }^{26}$ Wina Sanjaya. Op. Cit., hlm. 55.

${ }^{27}$ Hafi Anshari, Pengantar Ilmu Pendidikan, (Surabaya: Usaha Nasional, 1983), hlm. 90.

${ }^{28}$ Tim Kamus Pusat Pembinaan dan Pengembangan Bahasa, Kamus Besar Bahasa Indonesia. Op. Cit., hlm. 789.

${ }^{29}$ Tim Kamus Pusat Pembinaan dan Pengembangan Bahasa. Op. Cit., hlm. 896
} 
melaksanakan sesuatu, yang dalam hal ini membahas tentang masalah memberikan dan melaksanakan pendidikan agama Islam dalam keluarga, khususnya pendidikan dalam bidang media, metode, dan evaluasi.

Dari defenisi-defenisi problematika di atas sudah jelas bahwa problematika identik apa yang dimaksud dengan persoalan. Problematika adalah masalah atau persoalan dari pola pikir atau tingkah laku yang mengalami proses yang tidak terencanakan. Masalah atau persoalan tersebut merupakan titik awal suatu perubahan dilaksanakan demi perbaikan menurut proses tertentu pula. Problematika adalah wujud dari tindakan yang terbentuk kedalam suatu hal, yang bukan berarti problematika, bukan suatu kesalahan mutlak, dan suatu problem memang benar tidak dapat dimengerti dan dipahami.

\section{Metodologi Penelitian}

\section{Tempat Penelitian}

Lokasi penelitian ini dilakukan di sekolah (SMP) Negeri 5 Padang Sidimpuan. Penelitian ini dilaksanakan mulai bulan Mei sampai selesai tahun 2015 di sekolah SMP Negeri 5 Padangsidimpuan.

\section{Jenis Penelitian}

Berdasarkan sifat, karakteristik dan jenis data yang dibutuhkan, maka penelitian menggunakan metode kualitatif deskriftif.

\section{Sumber Data}

Data yang dibutuhkan dalam skripsi terdiri dari dua macam sumber, yaitu sumber data primer dan sekunder, sumber data tersebut antara lain:

a. Sumber data primer atau sumber data pokok yang dibutuhkan dalam penyusunan penelitian ini berasal dari guru Pendidikan Agama Islam, di SMP Negeri 5 Padangsidimpuan.

b. Sumber data sekunder atau pelengkap yang dibutuhkan dalam penelitian ini berasal dari kepala sekolah, dan SMP Negeri 5 Padangsidimpuan.

Jadi sumber data dalam penelitian ini adalah primer dan skunder yang diperoleh dari informan yang terkait dalam penelitian ini.

\section{Instrumen Pengumpulan Data}

Untuk mengumpulkan data yang dibutuhkan dalam penelitian ini, maka digunakan instrumen pengumpulan data sebagai berikut:

a. Observasi yaitu: suatu pengamatan langsung terhadap masyarakat dengan memperhatikan tingkah laku. ${ }^{30}$ Dengan demikian observasi yang penulis

${ }^{30}$ Slameto. Evaluasi Pendidikan, (Jakarta: Rineka Cipta, 1988), hlm. 93. 
laksanakan dengan terjun ke sekolah tersebut, kemudian melakukan pengamatan secara langsung tentang penomena pembelajaran Pendidikan Agama Islam yang dihadapi oleh siswa SMP Negeri 5 Padang Sidimpuan, dengan titik fokus pengamatan pada problematika pembelajaran.

b. Interviu, (wawancara), yaitu alat pengumpul informasi dengan cara mengajukan sejumlah pertanyaan secara lisan untuk dijawab secara lisan pula. $^{31}$

Berdasarkan penjelasan di atas, bahwa interviu yang dilakukan adalah alat pengumpulinformasi dengan cara mengajukan pertanyaan secara lisan untuk di jawab secara lisan pula, hal ini harus ada yang ditanya dan jawaban secara lisan pula untukmenemukan domain sebagai penyebab terjadinya problematika pembelajaran Pendidikan Agama Islam.

\section{Analisis Data}

Analisis data kualitatif adalah upaya yang dilakukan dengan jalan bekerja dengan data, mengorganisasikan data, memilah-milah menjadi satuan yang dapat dikelola, mensintesiskannya, mencari dan menemukan pola, menemukan apa yang penting dan apa yang dipelajari dan memutuskan apa yang dapat diceritakan kepada orang lain. ${ }^{32}$ Langkah-langkah yang digunakan dalam pengelolahan dan analisis data secara kualitatif dengan langkah-langkah sebagai berikut:

a. Reduksi data, yaitu memeriksa kelengkapan data untuk mencari yang masih kurang dan mengesampingkan yang tidak relevan.

b. Kategorisasi

1) Menyusun kategori. Kategori adalah upaya memilah-milah setiap satuan kedalam bagian-bagian yang memiliki kesamaan.

2) Setiap kategori diberi nama yang disebut "label".

c. Sintesisasi, mensintesiskan berarti mencari kaitan antara satu kategori dengan kategori yang lainnya kemudian di beri nama/label lagi.

d. Menyusun hipotesis kerja

Hipotesis kerja ini dilakukan dengan jalan merumuskan suatu pernyataan yang proposisional. Hipotesis kerja ini sudah merupakan teori substantif (teori yang berasal dan masih terkait dengan data). ${ }^{33}$

\footnotetext{
${ }^{31}$ Ibid., hlm. 165.

${ }^{32}$ Lexy J. Moleong. Metodologi Penelitian Kualitatif, (Bandung: Remaja Rosdakarya, 2000),
} hlm. 103.

${ }^{33} \mathrm{Ibid} .$, hlm. 217. 
Dapat diketahui bahwa untuk menjawab persoalan-persoalan yang terdapat pada rumusan masalah. Karena pengambilan kesimpulan dilakukan dengan cara induktif yaitu dari masalah yang sifatnya khusus disimpulkan menjadi yang sifatnya umum. Dengan kata lain berangkat dari fakta-fakta khusus atau peristiwa-peristiwa yang konkrit digeneralisasikan menjadi bersifat umum. Adapun yang menjadi rumusan masalah ada tiga yang dominan:

a. Menggambarkan problematika Pembelajaran Pendidikan Agama Islam

b. Menemukan problematika Pembelajaran Pendidikan Agama Islam

c. Menjelaskan terjadinya problematikaPendidikan Agama Islam yang dominan

\section{Hasil Penelitian}

\section{Temuan Umum}

\section{a. Keadaan Guru}

Berdasarkan hasil wawancara dengan kepala sekolah SMP Negeri 5 Padangsidimpuan bahwa guru tidak disiplin dan kurang professional menjadi masalah dalam proses pembelajaran. Sehingga kepala sekolah mengatakan lebih diutamakan mengajar daripada urusan pribadi, ini bertujuan untuk memperbaiki Sekolah kita ini. Guru yang tidak membuat Rencana Pelaksanaan Pembelajaran (RPP) setiap masuk di ruangan. Guru dalam mengajar kurang mampu menciptakan dan mengelola situasi kelas yang kondusif, membiarkan Siswa/siswi bercerita dengan temannya, sehingga mengganggu proses pembelajaran yang berlangsung. Hal ini sesuai observasi peneliti. Untuk mencapai pelaksanaan pembelajaran yang efektif dan kondisi ruangan kelas tentunya adalah faktor dari mengelola kelas yang baik, mengatur jumlah siswa dalam ruangan, tidak terlalu banyak dalam satu lokal, dengan begitu akan lebih semangat dalam belajar. ${ }^{34}$

Sejalan dengan observasi yang dilakukan oleh peneliti bahwa dalam proses pembelajaran masih ada kendala yang dihadapi baik sebelum kegiatan belajar mengajar sehingga terpaksa guru mengulangi pelajaran yang sudah disampaikan membuat waktu cepat habis. ${ }^{35}$

\section{b. Keadaan Murid}

Siswa adalah merupakan subjek didik dari proses belajar mengajar yang dilaksanakan di SMP Negeri 5 Padangsidimpuan. Berdasarkan data yang ada di

${ }^{34}$ Idrus, Kepala Sekolah SMP Negeri 5 Padangsidimpuan, Wawancara di SMP Negeri 5 Padangsidimpuan, Kamis, 17. Mei 2015.

${ }^{35}$ Bapak Mampa Luffi, S. Pd.I Guru Agama SMP Negeri 5 Padangsidimpuan, Wawancara di SMP Negeri 5 Padangsidimpuan, Jum'at 18 Mei 2015. 
SMP Negeri 5 Padangsidimpuan, maka keadaan siswa di SMP tersebut untuk tahun pelajaran 2014/2015 adalah sebagaimana yang terdapat pada tabel di bawah ini.

\begin{tabular}{|l|l|l|l|l|}
\hline No & Kelas & Laki-laki & Perempuan & F \\
\hline 1 & VII & 100 & 249 & 349 \\
2 & VIII & 108 & 230 & 338 \\
3 & XI & 100 & 157 & 257 \\
\hline & JUMLAH & 308 & 636 & 944 \\
\hline
\end{tabular}

Sumber: Data sekolah SMP Negeri 5 Padangsidimpuan ${ }^{36}$

Berdasarkan data di atas dapat diketahui bahwa siswa SMP Negeri 5 Padangsidimpuan Tenggara tahun 2014/2015 berjumlah orang yang terdiri dari orang laki-laki dan orang perempuan. Jumlah Siswa SMP sebelumnya, hal tersebut dikarenakan sistem pembelajaran sebagaimana mestinya.

\section{c. Keadaan Pelengkap Sarana dan Prasarana}

Proses belajar mengajar akan berjalan lancar jika didukung dengan sarana dan prasarana yang lengkap. ${ }^{37}$ Masalah fasilitas atau sarana merupakan masalah yang esensial dalam pendidikan, dari observasi penelitian, sarana dan prasarana Pendidikana Agama Islam di SMP Negeri 5 Padangsidimpuan adalah:

\begin{tabular}{|c|l|c|}
\hline No & \multicolumn{1}{|c|}{ Sarana Prasarana } & Keterangan \\
\hline 1 & Luas Bagunan & $2.289 \mathrm{~m}^{2}$ \\
& dan luas tanah & $8.344 \mathrm{~m}^{2}$ \\
\hline 2 & Ruang Belajar & 25 buah \\
\hline 3 & Ruang Laboratorium & 2 buah \\
\hline 4 & Ruang Guru & 1 buah \\
\hline 5 & Ruang Perpustakaan & 1 buah \\
\hline 6 & Ruang Kepala Sekolah & 1 buah \\
\hline 7 & Mushollah & 2 buah \\
\hline 8 & Sarana Olahraga & 1 buah \\
\hline 9 & Infokus & 2 buah \\
\hline 10 & Kantin & 4 buah \\
\hline 11 & Kamar Mandi & 1 buah \\
\hline 12 & Rumah pengajaran Kepala sekolah & \\
\hline
\end{tabular}

Sumber data: kantor tata usaha SMP Negeri 5 Padangsidimpuan 2014-2015

\footnotetext{
${ }^{36}$ Data sekolah SMP Negeri 5 Padangsidimpuan.

${ }^{37}$ Cece Wijaya dkk, Upaya Upaya Pembinaan Dalam Pendidikan dan Pengajaran (Bandung: PT Remajarosda Karya, 1992), hlm. 24
} 
Dengan demikian SMP ini telah memiliki sarana dan prasarana yang sangat bagus akan tetapi agar lebih bagus dalam pembelajaran harus memakai infokus supaya pembelajaran lebih mudah untuk diterangkan kepada siswa begitu juga agar siswa lebih mudah memahami pelajaran apa yang telah diajarkan guru Pendidikana Agama Islam.

\section{Temuan Khusus}

Pada temuan khusus yang akan dicantumkan data yang ditemukan di lapangan terdiri atas:

\section{a. Problematika Pembelajaran Pendidikan Agama Islam}

\section{1) Metode}

Metode dapat diartikan sebagai prosedur ataupun cara-cara yang digunakan dalam menyampaikan materi dalam proses belajar mengajar. Sesuai dengan sistem yang digunakan dalam pembelajaran Pendidikan Agama Islam di SMP Negeri 5 Padangsidimpuan.

Metode yang dominan digunakan dalam pembelajaran Pendidikan Agama Islam adalah metode ceramah. Jika hanya metode ceramah yang dilakukan dalam proses pembelajaran maka pembelajaran akan menurun disebabkan apabila pembelajaran Pendidikan Agama Islam dilakukan hanya dengan metode ceramah maka siswa tersebut akan jenuh dalam pembelajaran Pendidikan Agama Islam. Untuk menanggulagi hal tersebut seharusnya seorang guru Pendidikan Agama Islam menggabungkan metode caramah dan metode praktek supaya siswa tersebut tidak jenuh dalam pembelajaran Pendidikan Agama Islam. ${ }^{38}$

Kegiatan pembelajaran Pendidikan Agama Islam dilakukan hanya satu kali dalam seminggu dengan waktu 30 menit, dan metode yang digunakan: yang pertama ceramah yaitu menyampaikan sebuah materi pelajaran dengan cara penuturan lisan kepada siswa di dalam kelas, peran siswa disini sebagai penerima pesan, mendengarkan, dan mencatat keterangan guru bilamana diperlukan

Dengan demikian jelaslah bahwa dengan menggunakan metode ceramah yang dilakukan dalam pembelajaran maka pembelajaran akan menurun karena metode ceramah ini akan menbuat siswa merasa jenuh dan megantuk dalam pembelajaran.

\footnotetext{
${ }^{38}$ Observasi dengan Bapak Amir Hamzah, Guru Pendidikan Agama Islam, di SMP Negeri 5 Padangsidimpuan, Rabu Tanggal 13 Mei 2015.
} 
Dalam melaksanakan pembelajaran guru tersebut mengulang kembali pelajaran-pelajaran yang telah lewat sesuai dengan observasi yang penulis teliti dengan siswa SMP Negeri 5 Padangsidimpuan bahwa seorang guru tersebut mengulang kembali pelajaran Agama Islam.

Dilihat dari segi lainya bahwa ibu tersebut tidak membawa buku Agama kerumah Alasannya jika buku tersebut dibawa kerumah ditakutkan lupa membawa kembali kesekolah pada dasarnya melihat masalah diatas kalaulah seorang guru membawa buku Agama ke rumah maka lebih mudah memahami pelajaran selanjutnya sebelum memulai pelajaran seorang guru itu sudah memahami materi yang akan di ajarkannya pada waktu pembelajaran.

Dalam proses pembelajaran Pendidikan Agama Islam, guru bidang studi Agama tidak mempersiapkan berbagai program pembelajaran sebelum masuk kekelas seperti RPP, Prota, Prosem dan sebagainya. Tidak, karena para guru sudah memahami isi RPP yang direncanakan sebelum, pembelajaran berlangsung dalam proses kegiatan belajar mengajar guru bidang studi Agama tidak menggunakan media yang ada di sekolah seperti infokus, DVD, Tave recorder, $\mathrm{CD}$, dan lain-lain sehingga pemahaman siswa terhadap pelajaran Pendidikan Agama Islam berkurang. ${ }^{39}$

Jika melihat dari kedisiplinan siswa berdasarkan wawancara yang penulis lakukan di siplin siswa dalam belajarpun sangat rendah, dalam mendengarkan pembelajaran Pendidikan Agama Islam disiplin sangat kurang karena menurut mereka pembelajaran Pendidikan Agama Islam itu sangat sulit, pada dasarnya pembelajaran itu sangat mudah seperti dengan adanya memahami Agama maka lebih mudah memahami kitab suci Alquran.

Berdasarkan jumlah jam pelajaran Pendidikan Agama Islam, yang penulis observasi dengan guru Agama bahwa pembelajaran Pendidikan Agama Islam mengenai jumlah jam pembelajaran terbatas. Untuk mengantisipasi hal tersebut misalnya seorang guru tersebut pada waktu proses belajar mengajar menyuruh siswanya untuk menghapalkan materi pelajaran yang diberikan guru kepada siswa tersebut maka seorang guru itu harus bijak seperti guru tersebut melakukan tes lisan kepada siswanya yang sudah paham lalu seorang guru tersebut menyuruh siswanya yang sudah memahami pembelajaran Pendidikan Agama Islam itu mentes siswanya yang belum mengerti.

Berdasarkan observasi yang penulis lakukan dengan guru Pendidikan Agama Islam mengenai kehadiran siswa dalam pembelajaran Pendidikan

\footnotetext{
${ }^{39}$ Wawancara dengan Bapak Amir Hamzah, Guru Penddidikan Agama Islam di SMP Negeri 5 Padangsidimpuan, Rabu, Tanggal 13 Mei 2015.
} 
Agama Islam hanya di kelas $\mathrm{VII}^{3}$, di lokal $\mathrm{VII}^{5}$, orang yang tidak datang dalam pembelajaran Agama Islam dan pelajaran lainnya begitu juga kehadiran siswa yang sakit hanya satu orang dalam satu ruangan.

Jadi dengan demikian dapat dipahami apabila guru tersebut tidak disiplin dalam pembelajaran Agama maka kualitas pembelajaran akan menurun karena orang yang pertama kali yang berperan dalam dunia pendidikan adalah guru, dan guru disini sebagai contoh untuk siswa-siswanya apabila guru tersebut tidak tepat dalam memili metode maka siswa akan jenuh dalam belajar, untuk mengajar maka siswa tersebut akan malas untuk belajar begitu juga sebaliknya apabila guru tersebut bisa memilih metode yang tepat dalam menyampaikan pembelajaran Pendidikan Agama Islam maka akan berdampak positif pada siswanya dan akan rajin untuk mempelajarinya.

\section{2) Media}

Setiap proses pembelajaran baik lembaga formal maupun non formal membuthkan media. Media dapat membantu para guru dalam mentransfer ilmu kepada siswa. Penjelasan di atas mengandung makna bahwa dengan adanya media proses pembelajaran dapat mudah disampaikan dan diajarakan kepada siswa. Berdasarkan observasi peneliti di lapangan pada hari Rabu tanggal 14 Mei 2015 kondisi media pembelajaran di SMP Negeri 5 Padangsidimpuan sangat terbatas. Data di atas didukung dengan hasil wawancara pada hari jum'at tanggal 15 Mei 2015 Bapak Mampa Luffi, S.Pd bahwa media ada, seperti infokus hanya satu dan media yang lain seperti fraktek shalat, poster do'a-do'a, poster surah pendek dan lain-lain. Hal demikian tidak mencukupi dan sangat memprihatinkan dan pada akhirnya mengakibatkan kurang semangat siswa-siswi dalam belajar.

Jadi dapat disimpulkan bahwa kondisi ini hanya diperparah dengan tidak menggunakan media dalam proses pembelajaran Pendidikan Agama Islam dan tidak ada usaha guru dalam meningkatkan media pembelajaran di SMP Negeri 5 Padangsidimpuan.

\section{b. Analisis}

\section{1) Problematika Metode Pembelajaran}

Berdasarkan hasil wawancara yang penulis teliti menggunakan metode kurang tepat dalam menyampaikan tidak memberikan metode bervariasi, sehingga cara belajar siswa dalam pembelajaran Pendidikan Agama Islam adalah bahwa penguasaan Pendidikan Agama Islam mereka sangat berkurang disebabkan kurangnya memahami pelajaran Pendidikan Agama Islam yang dijelaskan guru kepada siswanya. Hal ini dapat dilihat dari hasil wawancara 
yang dilakukan peneliti terhadap siswa kelas $\mathrm{VII}^{4}$ hanya sebagian yang mau belajar dengan baik sebagian mereka hanya tidak menghormati gurunya waktu proses belajar mengajar pelajaran Pendidikan Agama Islam walaupun Belum mencapai $100 \% .^{40}$

\section{2) Problematika Media Pembelajaran}

Berdasarkan hasil wawancara yang penulis teliti menggunakan media cara belajar siswa dalam pembelajaran Pendidikan Agama Islam adalah bahwa penguasaan pembelajaran Agama Islam mereka sangat berkurang disebabkan kurangnya siswa memahami pelajaran Pendidikan Agama Islam yang dijelaskan guru kepada siswanya. Hal ini dapat dilihat dari hasil observasi yang dilakukan peneliti terhadap siswa kelas $\mathrm{VII}^{3}$ hanya sebagian yang mau belajar dengan baik sebagian mereka hanya tidak menghormati gurunya waktu proses belajar mengajar pelajaran Pendidikan Agama Islam walaupun Belum mencapai $100 \% .{ }^{41}$ Lebih lanjut, berdasarkan hasil wawancara penulis bahwa sebagian besar siswa sudah menerima pembelajaran dari gurunya akan tetapi masih banyak siswa yang belum mendapatkan pelajaran yang bagus dan target yang ditentukan. Tindak lanjut dari hasil belajar siswa, bagi siswa yang mendapatkan nilai bagus berdampak dengan nilai raportnya akan bagus dan siswa yang belum berhasil, seharusnya lebih giat untuk mempelajari Pendidikan Agama Islam.

Berdasarkan wawancara yang penulis lakukan dengan kepala sekolah dan guru begitu juga dengan siswa kelas VII ${ }^{3}$ SMP Dalam proses pembelajaran tidak menggunakan infokus, foster, atau pun radio, beberapa guru hanya menggunakan media begitu juga informasi yang penulis temukan dilapangan wawancara dengan siswa kelas $\mathrm{VII}^{4}$ terkadang mereka tidak dapat memahami pelajaran agama dikarenakan karena kawannya ribut sekali dalam proses pembelajaran akhirnya mereka tidak konsen dalam belajar tersebut kata mereka pelajaran Pendidikan Agama Islam itu enak akan tetapi karena kawan-kawan yang ribut dalam belajar, pada dasarnya pelajaran Agama itu tidak sulit asalkan ada kemauan untuk belajar tidak menutup kemungkinan Pendidikan Agama Islam tersebut bisa kita peroleh meskipun tidak dari guru bersangkutan. Dari

\footnotetext{
${ }^{40}$ Wawancara, dengan Bapak Amir Hamzah, Guru Bidang Studi Pendidikan Agama Islam di Sekolah SMP Negeri 5 Padangsidimpuan, Kamis, Tanggal 14 Mei 2015.

${ }^{41}$ Wawancara dengan Bapak Mamfa Luffi, Guru Bidang Studi Pendidikan Agama Islam SMP Negeri 5 Padangsidimpuan, Rabu, Tanggal 13 Mei 2015.
} 
sumber lain pembelajaran Pedidikan Agama Islam itu bisa kita dapatkan seperti dari buku Pendidikan Agama Islam. ${ }^{42}$

Berdasarkan wawancara penulis meneliti bahwa hasil belajar siswa sebagian besar belum dapat mengikuti pembelajaran akan tetapi sebagian sudah memahaminya. Untuk mengantisipasi hal demikian, seorang guru itu membuat jam tambahan bagi siswa yang belum memahaminya atau pun seorang guru itu memiliki kebijakan seperti seorang guru menyuruh siswa yang susah memahami pembelajaran Pendidikan Agama Islam mengajari siswanya yang belum memahami pelajaran Agama. Dengan demikian dapat disimpulkan bahwa siswa/siswi disini belum dapat memahami pelajaran Agama disebabkan gurunya kurang menguasai pembelajaran yang akan di sampaikannya akhirnya siswa di sini tidak dapat memperoleh nilai yang telah di targetkan.

\section{Kesimpulan}

\section{Penutup}

Berdasarkan masalah di atas setelah penulis melakukan penelitian langsung kelokasi dengan caramengadakan observasi dan wawancara, penulis mengambil kesimpulan bahwa:

a. Problematika metode pembelajaran Pendidikan Agama Islam (PAI) di SMP Negeri 5 Padangsidimpuanmetode, kurang sesuai dalam penetapan proses pembelajaran Bahwa metode pembelajaranyang dilakukan tidak sesuai dengan RPP. Contoh di RPP sudah disusun tetapi tidak sesuai dengan Rencana Pelaksanaan Pembelajaran, tidak bervariasi seperti metode ceramah, diskusi, metode Tanya jawab, hanya itu saja tidak dilakukan lagi metode yang lain seperti, metode demontrasi dan berdasarkan yang penulis lakukan bahwa masalah metode yang penulis temukan bermasalah.

b. Problematika media pembelajaran Pendidikan Agama Islam (PAI) di SMP Negeri 5 Padangsidimpuan sangat diklasipikasi kepada dua hal problematik, yaitu: problem ketersediaan media dan problem pemanfaatan media pembelajaran.

\section{Saran-saran}

a. Bagi guru Agama mampu meningkatkan penguasaan pengembangan materi dalam kegiatan belajar mengajar untuk memberikan materi-materi Pendidikan Agama Islam (PAI) yang berhubungan dengan disiplin ilmu lainnya, hendaknya menambahi metodenya, biasa dengan menggunakan

\footnotetext{
${ }^{42}$ Rahma, Siswa SMP Negeri 5 Padangsidimpuan, Observasi di SMP Negeri 5 Padangsidimpuan, Rabu, 13 Mei, 2015.
} 
metode diskusi, Tanya jawab, latihan dan lain sebagainya. Supaya para siswa lebih semangat lagi dan lebih termotivasi untuk belajar dengan menggunakan metode yang bervariasi. Agar pengetahuan siswa/siswi lebih berkembang. Mempergunakan media danfasilitas yang ada pada saat belajar mengajar berlangsung, guna agar siswa tidak bosan dalam belajar. Para guru memperketat kedisiplinan para siswa dalam belajar dan memberikan motivasi kepada siswa/siwi, sehingga senang dalam belajar.

b. Kepada orangtua disarankan agar terus memberikan dukungan terhadap pembelajaran Pendidikan Agama Islam terutama ketika anak berada dalam keluarga, para orangtua harus memberikan bimbingan, nasehat, supaya pembelajaran Pendidikan Agama Islam di SMP Negeri 5 Padangsidimpuan Berjalan denga baik.

c. Kepada kepala sekolah SMP Negeri 5 Padangsidimpuan, disarankan agar melengkapi kekurangan fasilitas/sarana SMPNegeri 5 Padangsidimpuan ini, Agar pembelajaran Pendidikan Agama Islam di SMP Negeri 5 Padangsidimpuan berjalan dengan efektif.

\section{Referensi}

Abd Azis Albone, Pendidikan Agama Islam dalam Persfektif Multikulturalisme, Jakarta: Cipta Mandiri, 2006.

Abuddin Nata, Filsafat Pendidikan Islam, Jakarta: Logos Wacana Ilmu, 1997.

Asfiati, Manajemen Pembelajaran Pendidikan Agama Islam, Bandung: Citapustaka Media, 2013.

Cece Wijaya dkk, Upaya Upaya Pembinaan dalam Pendidikan dan Pengajaran, Bandung: PT Remajarosda Karya, 1992.

Depag, Undang-undang dan Pemerintahan RI tentang Pendidikan, Jakarta: Dirjen Pendidikan Islam Departemen Agama RI, 2006.

Dimyati, Belajar dan Pembelajaran, Jakarta: Rineka Cipta, 2006.

Hafi Anshari, Pengantar Ilmu Pendidikan, Surabaya: Usaha Nasional, 1983.

Haidar Putra, Pendidikan Islam di Indonesia, Jakarta: Cita Pustaka Media, 2001.

Hasbullah, Dasar-dasar Ilmu Pendidikan, Bandung: Wacana Prima, 2007.

Lexy J. Moleong. Metodologi Penelitian Kualitatif, Bandung: Remaja Rosdakarya, 2000.

Mardianto, Media Pembelajaran Pendidikan Agama Islam, Medan: Fakultas Tarbiyah Istitut Agama Islam Negeri Sumatera Utara, 2010.

Muhaimin, Paradigma Pendidikan Islam, Bandung: PT. Remaja Rosdakarya, 2002. Ngalim Purwanto, Psikologi Pendidikan, Bandung Remaja Rosdakarya, 1990. 
Oemar Hamalik, Kurikulum dan Pembelajaran, Jakarta: Bumi Aksara, 2008.

Slameto. Evaluasi Pendidikan, Jakarta: Rineka Cipta, 1988.

Sukanto, Pengembangan Kurikulum, Medan: Fakultas Tarbiyah Istitut Agama Islam Negeri Sumatera Utara, 2010.

Syafaruddin, Ilmu Pendidikan Perspektif Islam, Bandung: Citapustaka Media, 2005.

Syaiful Bahri Djamarah dan Aswan Zain, Strategi Belajar Mengajar, Jakarta: Rineka Cipta, 2006.

Syaiful Sagala, Konsep dan Makna Pembelajaran, Bandung: Alfabeta 2013.

Tim Penyusun Departemen Pendidikan dan Kebudayaan, Kamus Besar Bahasa Indonesia, Jakarta: Balai Pustaka, 1991.

Toto Ruhimat, Kurikulum\& Pembelajaran, Jakarta: PT. Raja Grafindo Persada, 2011.

Undang-Undang Sistem Pendidikan Nasional, Media Wacana Press, Jogjakarta: Cet. I, 2003.

Wina Sanjaya, Strategi Pembelajaran Berorientasi Standar Proses Pendidikan Jakarta: Kencana, 2008. 